\title{
HMM-SOM に基づく認知行動の獲得と光の学習 \\ Learning of Cognitive Action based on Self-organizing Maps with HMMs
}

\author{
青山 一美 \\ ソニー株式会社 \\ Sony Corporation \\ Kazumi.Aoyama@jp. sony.com \\ 南野 活樹
Katsuki Minamino \\ 下村 秀樹 \\ Hideki Shimomura \\ (同上卡) \\ Katsuki.Minamino@jp. sony.com \\ (同上) \\ Hideki.Shimomura@jp.sony.com
}

keywords: HMM-SOM,SOM, HMM, cognitive behavior system, developmental robotics

\section{Summary}

An autonomous agent in the real world should learn its own sensor-motor coordination through interactions with the environment; otherwise the behaviors can not be grounded and they can easily be inappropriate in the variety of the environment. The sensor-motor signals are usually complex time sequence, therefore the cognitive action system of the agent has to handle them.In this paper, we propose a computational model of the cognitive action system that consists of a sensor space HMM-SOM, a motor space HMM-SOM and connection mapping between the two HMM-SOMs. A HMM-SOM can be recognized as a set of HMMs that are placed in a SOM space. It can model a set of complex time series signal in a self-organizing manner.We apply this HMM-SOM based cognitive action system on vision-motion and auditory-articulation signals. The experimental results show that this system is basically capable of constructing sensor-motor coordination structure in a self-organizing manner, handling complex time series signals.

\section{1.はじめに}

近年, 自律エージェントに関する研究が活発に行われ ており, 谷のひとつの応用例である自律型ロボットへの 関心も高まってきている. 我々も, 実世界で人を飽きさせ ずに長期間のインタラクションが可能な自律エージェン 卜の実現を目標として検討を重ねている.我々はこれま でロボットの認識と行動をデザインし,あらかじめロボッ 卜に作りこむ手法をとり,自律型ロボットを開発してきた [Fujita 03]. このアプローチは, 開発者が事前に想定した 環境に対して行動を規定していくものである. しかし一般 に実世界は, 事前に想定できない状況を多分に含むもの であり, 開発者がすべての環境に対する行動を規定して おくことは難しい. これに対し, ロボティクスの分野では 発達や創発に基づくアプローチか提案されている [Asada 01]. このアプローチを広く捉えれば, 自律エージェントの 持つ認知行動システムが環境との相互作用を通して発達 し, 自律行動全体を創発するシステムを追求するものと 特徵づけることができる. この方法論はまだ確立された とはいえないものの, 与えられた環境内でエージェントが 適切な行動を獲得できる可能性のある, 有望な方法のひ とつである. 我々も, 作りこみによるアプローチの反省か
ら,センサ-モータの関係を環境とのインタラクションか ら学習していく, すなわち認知行動システムを発達させ ていくアプローチを試みている. その中でも, 認知行動の 獲得において重要な役割を果たすものとして, 模倣や教 示に着目している.

人間が音声を獲得していく例を考えてみよう. 乳幼児 は, 自身が出す音声に対して親などの養育者が似た音を まねて応答することで, まず聴覚と調音の対応関係を獲 得するといわれている [Masataka 93]. さらに乳幼児は, この養育者の発声をまねて発声することが知られている. 自身の発声を養育者の発声と比較し, 弚れに近づくよう に発声運動を調整した結果, より明瞭な発声が可能になつ ていくと考えられる.このように養育者の「まねる」行為 と乳幼児の「まねる」行為の双方によって, 乳幼児は聴覚 と対応する音の発声方法を学習していく.

この音声言語獲得, あるいはとれに匹敵するような認知 発達現象を機械で実現することを考えるとき, 光の学習メ カニズムには次のような機能・特性が求められる. 第一に, センサ, モータ共に複杂倠な多次元時系列を扱えねばならな い. 人間の音声の場合には, センサは聴覚, モータは発声 
器官への運動指示に相当する. 呂れらを表現する信号は， 多次元時系列でかつ非常に複雑である. 第二に, 教師ラべ ルが与えられずにカテゴリを学習できる必要がある.た とえば, 音声を認識技術の視点で取扱うほとんどの場合， 学習データには認識結果に相当するカテゴリ情報が付与 されており, 弚れに基づいて HMM などにモデル化して 学習している.しかし, 実環境ではカテゴリに関する明確 な情報は与えられない. 弚のため, 自らの尺度に従ってカ テゴリに類するものを作れる学習アルゴリズムが必要と なる. 第三に, 学習したことのない未知の入力に対しても 妥当な出力をできる能力を持つ必要がある. 実環境では, 既知の入力のみではなく, 未知の信号も入力されるので, 少ない経験から未知の入力に対する妥当な出力が可能な 認知行動システムを形成する必要がある. 光のためには, 経験した認知行動を個別に学習するのではなく,複数の 認知行動の関係を構造として得るように学習し, 弚の認 知行動の間の中間的な表現も形成されていくこと,すな わち異なる認知行動間の内挿も同時に学習されることが 要件のひとつとして考えられる

我々はこれまでに,センサ空間やモータ空間で多次元の 時系列データを自己組織的に学習する,隠れマルコフモデ ルを自己組織化マップ上に配置した手法 Self-Oraganizing Map with HMMs(HMM-SOM) を提案している $[\mathrm{Mi}-$ namino 05].HMM は, 時間伸縮のある多次元の時系列 信号を効率的にモデル化することができ, 音声認識など で広く利用されている. 兴れを SOM 上に配置して自己組 織化することによって, 多次元時系列信号の自己組織化 を狙ったのが HMM-SOM である. 本稿ではこの HMMSOM を道具として用い, 入力信号を捉える知覚層, 出力 信号を生成する生成層を構成し, 弚の間の写像 (以下, 結 合層と呼ぶ）としてセンサ-モータの関係を学習する認知 行動システムを提案する. 認知行動システム全体として, 複数経験の内捚表現を得るためには, 知覚層, 生成層, 結 合層が光れ光れ内挿表現を生むための構造を持っている 必要がある. 提案する認知行動システムは, 知覚層と生成 層は HMM-SOM を用いた自己組織化学習,結合層 Hebb 則の拡張を用いた学習を行うことで,この内挿表現が形 成されることを狙っている.もちろんこの方法の適用対象 は,これまでの議論の例に挙がっている音声げけに限定さ れない.一般的なセンサ-モー夕信号の自己組織的学習に も適用可能である.

本稿の構成を以下に示す. まず,多次元の時系列データ を自己組織化学習する技術として,HMM と SOM を組み 合わせた新しい学習メカニズム HMM-SOM を概説する. 次に, この新しい学習メカニズムによってセンサ信号と モータ信号を自己組織的に学習し，同時にこの 2 者の写 像関係を学習していくことにより, 系全体として多次元 の時系列信号同士の非線形で複雑な関係を学習すること が可能な,認知行動システムを提案する.さらに, 提案し たシステムの基本能力の検証として入出力信号に視覚-運
動の時系列信号を対応させた例を示した後, 音声を用い た「聞きまね」の実験例を示す.乥して関連研究について 我々のアプローチとの比較を述べ, 最後に今後の課題につ いて言及する。

\section{HMM-SOM による時系列データの自己 組織化学習}

ここでは, 提案するシステムの中核技術である, 時系列 データの自己組織化学習メカニズムについて概説する.詳 細は [Minamino 05] に述べられているが, コンセプトと 学習手法について簡単に説明する.

\section{$2 \cdot 1$ 学習アルゴリズム}

入力されるデータを自己組織的に分類するアルゴリズム として,自己組織化マップ (SOM:Self-Organizing Maps) [Kohonen 95] が挙げられる.SOM の学習アルゴリズムで は,N 次元のベクトルを入力として,SOM のトポロジーが 規定する次元で入力パターンを表現できるように学習す る. 光の結果,SOM の出力層に配置されたノードは, 弚れ ぞれある特定の入力信号パターンに反応しやすくなる特 性を持つようになる. また, 多次元の入力データベクトル をSOM のトポロジーが定める次元で表現するため, 入力 データベクトルの低次元化を実現している.しかし SOM は一般に, 静的な信号パターンであるべクトルを扱うも のである.

一方で, 複雑な時系列信号をモデル化する手法として, 代表的なものに隠れマルコフモデル (HMM:Hidden Marcov Model) があげられる.HMM は, 音声認識の分野で広 く利用されている.HMM の学習では, あらかじめカテゴ リ分けされた時系列信号を用いて学習を行う，教師つき 学習が適用されることが多い.

我々はこの両者を組み合わせ, 時系列信号の自己組織化 学習を可能にした HMM-SOM(Self-Organaizing Map with HMMs) を提案している.SOM では, 各ノードが入 カデータ空間の特性をベクトルで表現する (このベクト ルを参照ベクトルと呼ぶ）のに対し,HMM-SOM では, 光 れを HMMによって表現する. この利点は,HMMによる 時系列信号のモデル化と,SOM による構造化, 低次元化 の双方が可能であることである.

以下, 学習アルゴリズムについて説明する.一般的な $\operatorname{SOM}$ (図 1) の学習は以下の手順によって進められる.

Step1 弚れ枈れのノード $n_{i}(i=1,2 \ldots N)$ の参照べク トル $\mathbf{m}_{i}$ の初期值をランダムに設定する.

Step2 ある入力ベクトル $\mathrm{x}(t)$ に対して最も近い参照ベ クトルを持つ勝者ノードを決定する.

Step3 勝者ノード $n_{w i n}$ の参照ベクトル $\mathbf{m}_{w i n}$ を入力 ベクトルに近づけ, さらに近傍ノードの参照べクト ルに関しても,SOM 上での勝者ノードからの距離に 応じて入力ベクトルに近づける. 


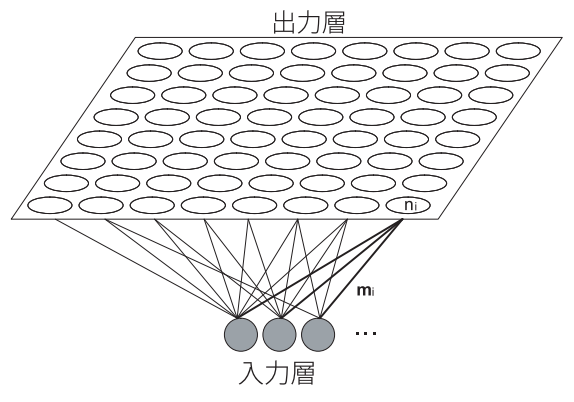

図 $1 \quad \mathrm{SOM}$ (Self-Organizing Map)

Step4 Step2,Step3 を, 学習が進むにつれて学習対象と

する近傍のノード数を狭めていきながら繰り返す.

Step3での参照ベクトルの更新は, 以下の更新則によって 与えられる.

$$
\mathbf{m}_{i}(t+1)=\mathbf{m}_{i}(t)+h(d)\left(\mathbf{x}(t)-\mathbf{m}_{i}(t)\right)
$$

ここで, $t=0,1,2 \ldots$ はイタレーションの回数, すなわち学 習回数を表す. また, $h(d)$ は近傍関数と呼ばれ, 参照べク トル $\mathbf{m}_{i}(t)$ をどの程度入力ベクトル $\mathrm{x}(t)$ に近づけるか を決定する. 近傍関数 $h(d)$ は, 以下の式によって与えら れる.

$$
\begin{gathered}
h(d)=\alpha \frac{1}{\sqrt{2 \pi} \sigma} e^{\frac{-d / 2}{2 \sigma^{2}}} \\
d=\left\|n_{\text {win }}-n_{i}\right\|
\end{gathered}
$$

但し, $\left\|n_{i}-n_{j}\right\|$ は $\mathrm{SOM}$ 上のノード $n_{i}, n_{j}$ 間の距離を表 す.距離は例えばユークリッド距離や, ノード間のリンク 長などで定義される. 係数 $\alpha$ は学習係数, $\sigma$ は近傍の幅を 決定するパラメータ,d $d \mathrm{SOM}$ 上での勝者ノード $n_{\text {win }}$ からの距離である.

この SOM 上のノードが備える参照ベクトルを HMM に 置き換えたものが, 提案した HMM-SOM である.HMMSOM では, 時系列の入力信号に対して最も尤度の高い参 照 HMM を持つ SOM 上のノードを勝者ノードとして決 定する. 乥して SOM と同樣, 勝者ノードを中心とした近

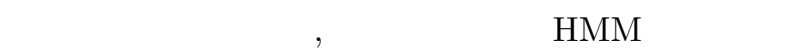
タを入力データに近づけるよう, パラメータ更新を行う (図 2). 入力信号が与えられ, 学習が進むに従って,HMM$\mathrm{SOM}$ 上の参照 HMM はある時系列信号パターンを, 光の 近傍の参照 HMM は類似したパターンをモデル化したも のとなる.HMM-SOM の学習アルゴリズムを以下に示す. Step1 HMM-SOM 上のノード $n_{i}$ に備えられた参照 $\mathrm{HMM} \mathrm{h} m m_{i}$ に初期值としてランダムなパラメータ を設定する.

Step2 ある時系列データの入力 $\mathrm{X}(t)$ に対して,Viterbi アルゴリズムによりすべての $\mathrm{h} m m_{i}$ の尤度を計算 する.X $(t)$ は 1 フレームが多次元のべクトル $\mathrm{x}_{k}$ で フレーム長 $l$ 時系列データ $\left(=\left(\mathrm{x}_{1}, \mathrm{x}_{2}, \ldots \mathrm{x}_{l}\right)\right)$ であ

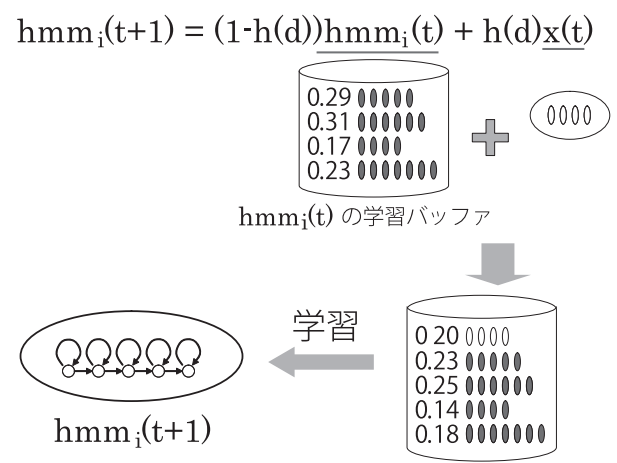

図 2 HMM-SOM での重みの更新

る. この中で尤度の最も高い参照 HMM を持つノー ド $n_{\text {win }}$ を,HMM-SOM における勝者ノードとして 決定する.

Step3 勝者ノード $n_{w i n}$ の参照 HMM を $\mathrm{X}(t)$ に近づ けるように学習する.さらに近傍ノードの参照 HMM に関しても,HMM-SOM 上での勝者ノードからの距 離に応じて入力時系列データに近づける.

Step4 Step2,Step3を,学習が進むにつれて学習対象と する近傍のノード数を狭めていきながら繰り返す.

Step3 での HMM のパラメータ更新は, 一般的な SOM では式 (1) に相当する演算を行うこととなる. 具体的に は, 参照 HMM にモデル化された時系列信号を, 学習係数 $h(d)$ で入力時系列信号 $\mathbf{X}(t)$ に近づけることを意味する. しかし, 入力は時系列データ $\mathbf{X}(t)$ であり,HMM-SOM の 持つ参照 HMM は HMM のパラメータによって表現さ れているため, 同樣の演算を直接行うことが出来ない. 兴 こで, 式 (1)の変形から実装を考える.

$$
\mathbf{m}_{i}(t+1)=(1-h(d)) \mathbf{m}_{i}(t)+h(d) \mathbf{x}(t)
$$

式 (4) をHMM のパラメータ更新式の視点で考えると,あ る $\mathrm{HMM}$ に対して, $\mathbf{X}(t)$ という時系列データを学習デー タとして重み付きで加え，再度 HMM のパラメータを推定 する演算と解釈することができる. 通常の HMM の学習で は, 時系列信号の集合を学習データとして Baum-Welch のアルゴリズムによりパラメータ推定を行うため, このよ うな逐次的な演算を兴のまま行うことができない. 弚こ で, 参照 HMM ごとに学習に用いるデータを保持するバッ ファ(以下, 学習バッファと呼ぶ) を持たせ, 弚れによって HMM のパラメータを推定するよう実装した. 学習バッ ファのデータ内容は逐次更新する. 学習バッファには, 学 習データが重み付きで複数保持されている. 重みの総和は

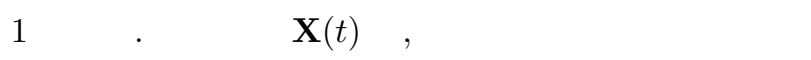
習バッファに, 学習の重み $h(d)$ とともに蓄積される. 同 時に,これまでの学習データの重みの総和が $1-h(d)$ と なるようにバッファ内の重みか調整される (図 2). 調整時 には, 実装上重みが 0 に近い値の学習データを削除する. 例えば, 次節以降で説明する実験では, 重み 0.01 以下の学 
習データは削除し学習には使用していない. この学習バッ ファを利用して,HMM を再度学習することにより, 勝者 ノードと光の近傍の HMM のパラメータを入力データに 対して尤度が高くなるように変更する*1.

\section{$2 \cdot 2$ 認 識と生 成}

学習後の HMM-SOM は,ある時系列の入力データを認 識する認識装置として捉えることができる.つまり, 入力 信号に対する HMM-SOM 上の参照 HMM の尤度を計算 することで,最も入力信号をモデル化している参照 HMM を決定することができる. また, 学習後の HMM-SOM の 参照 HMM を用いて, 時系列データを生成することも可 能である [Minamino 05]. このことから,HMM-SOM は 各ノードが保持する HMM のパラメータに基づいて時系 列パターンを出力できる, 時系列データ生成器とみなす こともできる.HMM-SOM を用いて時系列信号を自己組 織的に学習することで, 低次元化した SOM の空間には学 習データ群の持つ構造 (カテゴリ構造) カ現れる. 德永ら の提案する $\mathrm{mnSOM}[$ Tokunaga 05$]$ では,SOM 上に関数 モジュールを配置し, 弚の関数群を自己組織的に学習し, 兴の結果学習しなかった中間的な関数を自己組織的に生 成することを確認している. 本稿で提案する HMM-SOM においても学習データを表現する HMM-SOM 上のノー ド間には, 複数の学習データから学習されたノードが形 成される. この参照 HMM は学習データ間の内挿を表現 するものと期待できる.このノードによって学習していな い多次元の時系列信号を認識, 生成できるようになるこ とが HMM-SOM を用いて自己組織化学習をすることの 目的である.

\section{3. 提案する認知行動システムと学習手法}

ここでは,センサ信号を自己組織的に学習した知覚層, モータ信号を自己組織的に学習した生成層, 両者の間の 写像の 3 つのモジュールによって構成した認知行動シス テムを提案する.

\section{$3 \cdot 1$ システム構成と学習手法}

提案する認知行動システムを図 3 に示す.このシステ ムは, センサ入力の時系列信号を扱う HMM-SOM(知覚 層) と, モ一タ出力の時系列信号を扱う HMM-SOM(生成 層)を用意し，弚れ洞士を 全結合したものになっている.この結合重みは, 知覚層の ノードと生成層のノードの関連の強さを表す.このシス テム全体の学習アルゴリズムを以下に示す. 結合重みの 更新の詳細については後述する.

Step1 知覚層と,生成層の参照 HMM を適当なパラメー タで初期化する. また結合重みも小さな值で初期化

*1 重み付きの学習データに対する HMM のパラメータ更新則 については付録 A に示す

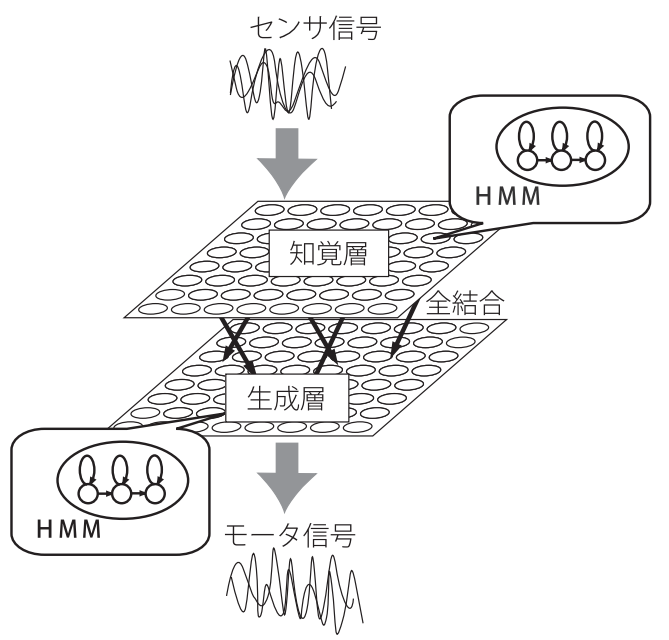

図 3 HMM-SOM を用いた認知行動システム

する.

Step2 学習データとして, センサ入力信号と光の入力 に対応するモータ出力信号を与える.

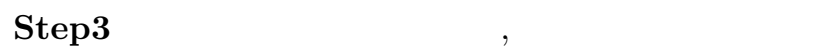
己組織化学習を行う. 時系列データの自己組織化学 習は HMM-SOM の学習法に従う.

Step4 両平面間のノードの結合重みを更新する.

Step5 学習データが入力される度に,Step2 から Step4 を繰り返す。

\section{$3 \cdot 2$ 結合重みの学習}

Step4 の結合重みの更新は Hebb の学習則 [Hebb 49] を拡張し, 発火したノード同士の結合を最も強化し, 弚の 周辺の結合にも影響を及ぼすような学習則を適用してい る.ここで知覚層のノードを $n_{i}^{p}(i=1,2 \ldots N)$, 生成層の ノードを $n_{j}^{g}(j=1,2 \ldots M)$ とする. 結合重み $w_{i j}$ は, 知覚 層の勝者ノード $n_{w i n}^{p}$ と生成層の各ノード $n_{j}^{g}$ の結合重み $w_{w i n, j}$ と, 知覚層の各ノード $n_{i}^{p}$ と生成層の勝者ノード $n_{\text {win }}^{g}$ の結合重み $w_{i, w i n}$ を更新する. この結合重みの更新 則は以下の式で表現される. $\alpha$ は学習率を表す.

$$
\begin{gathered}
w_{\text {win }, j}(t+1)=(1-\alpha) w_{\text {win }, j}(t)+\alpha \Delta w_{\text {win }, j} \\
w_{i, \text { win }}(t+1)=(1-\alpha) w_{i, \text { win }}(t)+\alpha \Delta w_{i, \text { win }} \\
\Delta w_{\text {win }, j}=\frac{1}{\left\|n_{\text {win }}^{g}-n_{j}^{g}\right\|+1} \\
\Delta w_{i, \text { win }}=\frac{1}{\left\|n_{\text {win }}^{p}-n_{i}^{p}\right\|+1}
\end{gathered}
$$

\section{$3 \cdot 3$ 認知行動システム}

こうして学習した認知行動システムは, 環境からある 時系列のセンサ信号が入ってきたときに, 知覚層-生成層 


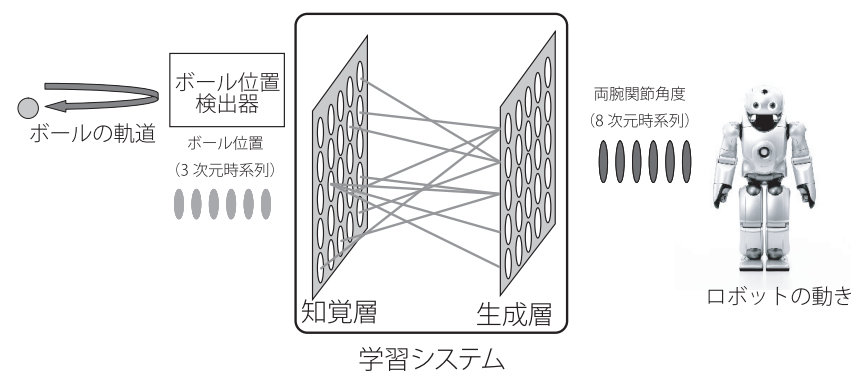

図 4 視覚-運動の対応システム図

の写像を通して, 弚れに対応する時系列のモ一夕信号を出 力することが可能になる. これは, ある時系列のセンサ信 号に対して, 知覚層上で最も尤度の高い, すなわち勝者の ノードを決定し，光のノードと最も高い結合重みを持つ， 生成層のノードの参照 HMM から, 時系列のモ一夕信号 を出力することで実現できる.

\section{4. 実 験}

提案した認知行動システムを実装し, 検証した. まず初 めに, 比較的低次元の信号を用い, センサ信号, モ一夕信 号, また关の間の写像が自己組織的に学習可能であるこ との基礎検証結果を示す.具体的には, ロボットの視覚へ の信号と関節角度列の信号の対応関係を学習した. 次に, 音声データを用い, 多次元の時系列信号を自己組織的に 学習する例を示す。

\section{$4 \cdot 1$ 視覚-運動の対応付けシステム}

\section{$\S 1$ 実験環境}

センサ入力とモータ出力に対して視覚-運動を対応させ て学習させた例を示す. 全体のシステムを図 4 に示す.こ の実験では, ロボットに対面する人の動かすボールの軌 道と対応するロボットの動きのパターンを認知行動シス テムに与えて学習させた. 実験に使用したロボットは,ソ ニーが開発した二足歩行ロボット [Fujita 03] である. こ のロボットは両目のカメラによって, ロボットのボディ中 心座標系でのボールの重心座標 $(x, y, z)$ を観測する. ま た, 自身の腕の関節角度のデータ (両腕合わせて 8 次元) も観測することができる. 教示データは, 以下の 3 つの周 期運動を光れ約 5 分ずつサンプリング周期 $72 \mathrm{msec}$ で収録した。

1）ボールの軌道縦方向に対して，ロボットの両手を縦 方向に動かす,

2) ボールの軌道横方向に対して, ロボットの両手を横 方向に動かす,

3) ボールの軌道が円を描くのに対して, ロボットの両 手で円を描く。

この 3 つのパターンは人が見たときに, 視覚入力の動き と, ロボットの動きのパターンが「動きのみまね」をし
ているような対応付けにした. 具体的には, 1 人の教示者 がロボットと対面してボールを動かし, 弚れに合わせて もう 1 人の教示者がロボットの両腕を持ち, 対応するロ ボットの動きを直接教示した. 教示データ収録の樣子を図 5 に示す.このデータを $2100 \mathrm{msec}$ ずつ分割し, 学習デー タとする ${ }^{* 2}$. 学習時には, 知覚層への 3 次元, 生成層への 8 次元の学習データが入力される毎に, 知覚層と生成層の 学習を行い, 知覚層の勝者ノード, 生成層の勝者ノードを 中心にして,HMM-SOM の参照 HMM のパラメータと結 合重みを更新する.この学習を 1 イタレーションとして， 收録した学習データ 1)1088 個,2)1044 個,3)797 個から毎 回ランダムに学習データを選択し, 合計 10000 回のイタ レーション学習を行った. 知覚層と生成層の HMM-SOM が持つノードの数は 100 とした.ノード数は, 本実験で は同じカテゴリでも周期運動の位相が異なるものが入力 されるため,いくつかの試行の結果, 1 カテゴリあたり約 30 個程度のノード数に設定した. また,SOM 空間のトポ ロジーを $10 \times 10$ のトーラス状に定めた.トーラス状とは 2 次元平面に配置されたノードの上下と左右の両端にも 結合があるようなトポロジーを規定したものである (図 6). このようにSOM の規定する空間を作ることによっ て HMM-SOM 上に端がなくなり, 近傍領域がどのノー ドにとっても一樣になる. この空間での距離は, 図 6 のよ うにノードをリンクで結んだ場合の,ノード間の最小リ ンク数とした.式 (2) における $\alpha, \sigma$ の值は学習総回数を $\mathrm{T}$, 現在の学習を $\mathrm{t}$ 回目のとき, 以下の式によって決定し た. この結果, 式 $(2)$ における $h(d)$ は $t$ の関数 $h(d, t)$ と なり,SOM の近傍学習の幅が時間とともに狭くなるよう に学習が進む。

$$
\begin{aligned}
& \alpha=\alpha_{0}\left(1-\frac{t}{T}\right) \\
& \sigma=\sigma_{0}\left(1-\frac{t}{T}\right)
\end{aligned}
$$

今回の実験では, 学習初期には HMM-SOM 上のすべて のノードで参照 HMM のパラメータ更新が行われ,かつ 勝者ノードの学習バッファの中身が全体の $5 \%$ 程度ずつ 変更されるよう, $\alpha_{0}=0.4, \sigma_{0}=3.0$ とした. また, 弚れ光 れの HMM-SOM のノードの重みを表現する参照 HMM は,10 状態の left-to-right 型の HMM で構成した. これ らのパラメータは,計算量, 自己組織化の進み具合を考慮 し, 数回の試行の上で決定した.

\footnotetext{
$* 2$ 学習データは開始位置を $350 \mathrm{msec}$ ずつずらし, 重複させな がら分割した. このフレーム長 $2100 \mathrm{msec}$ は, 学習後の認知行 動システムの動作確認のため, ロボットが出力した動作が何を しているかかわかる程度の長さ,すなわち一周期以上含まれる ようにした.
} 


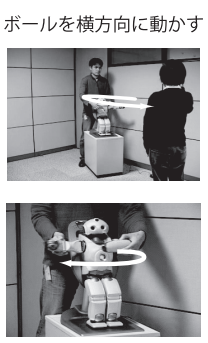

横の運動を教える
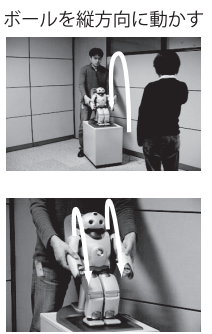

縦の運動を教える
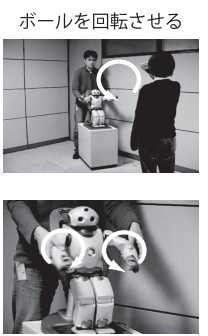

円運動を教える
図 5 教示の樣子

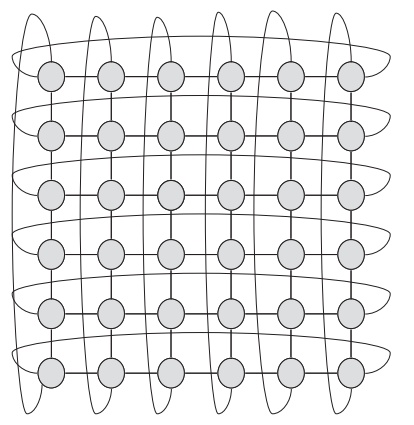

図 6 トーラス状

\section{$\S 2$ 実験結果と考察}

上記の学習を行った後, このシステムが, 知覚層, 生成 層, 結合重みを光れ光れ自己組織的に学習できているか の評価を行った.また認知行動システム全体として,セン サ信号を観測した際に, 適切な行動が出力できるかを確 かめるため, ロボットを用いて動作の確認を行った.

まず, 乥れぞれの学習後の HMM-SOM の構造を解析し た. 学習結果として得られた平面を図 7 に示す. 図の上部

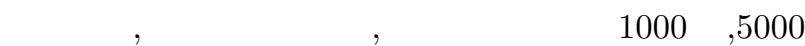
回,10000 回のときの学習バッファの情報である. $2 \cdot 1$ 節 で説明した通り, 学習バッファには, 学習時に入力として 与えられた時系列信号が重みつきで蓄えられる.この学 習データには, 評価用として 1) 横動き 2) 縦動き 3 ) 円運 動の 3 パターンを見分けるカテゴリラベルを付与してあ る. このカテゴリラベルを用いて, 学習バッファ中に蓄え られている学習データの重みをカテゴリラベル毎に累積 し, 各学習バッファに対する各カテゴリの重みの割合を 求めた. 図 7 の内部にある棒グラフには, カテゴリ毎の重 み割合が示されている. このグラフから, 知覚層, 生成層 共に学習が進むに従って, ある特定のカテゴリによって 学習バッファが占められたノードが HMM-SOM 上に領 域を持って形成されていく樣子が分かる.例えば,生成層 での円運動 (図中では白) に着目すると, 学習 1000 回目 では HMM-SOM の中央付近にぼんやりと集まる. 学習 5000 回になると円運動の学習データが支配的となった ノードは左中央に偏り,10000 回でそれがより鮮明になる. 他の領域も, 学習バッファが特定の学習データで占めら れたノードで構成されるようになった. この領域の区分
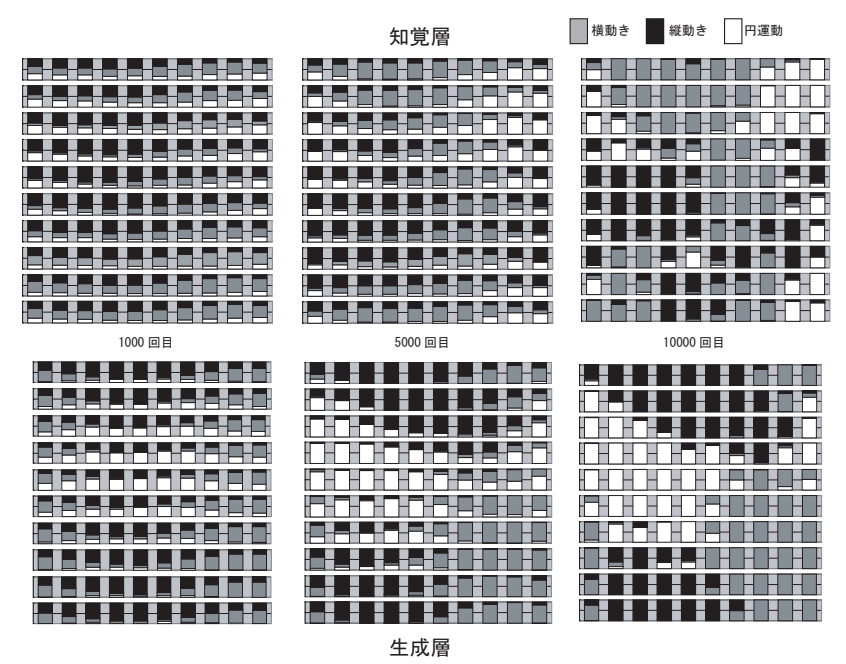

図 7 知覚層, 生成層の学習の樣子

や配置は, 参照 HMM に設定した初期パラメータの值や， 学習データを与える順序によって異なる. しかし複数回 試行したどの場合においても, 学習回数が進むにつれて, ある特定カテゴリで学習バッファが占められるノードが HMM-SOM 上に領域を持って形成されていくことを確 認した

次に, 性能の定量化を試みた. まず, 知覚層, 生成層の各 ノードの学習バッファ中に最も多く含まれるカテゴリを, 擬似カテゴリラベルとして, 弚れ光れのノードに割り当て た. 乥して, 評価データとして, 学習データとは別のボー ルの軌道データを 1)365 個,2)344 個,3)260 個の計 969 個 用意した. この評価データを入力したときのa) 評価デー タの正解ラベルと発火した知覚層のノードの擬似ラベル との一致率 (知覚層),b) 評価データに発火した知覚層の ノードの擬似ラベルと最も高い結合重みを持つ生成層の ノードの擬似ラベルの一致率 (結合),c) 評価データの正解 ラベルと知覚層の勝者ノードと最も高い結合重みを持つ 生成層のノードの擬似ラベルとの一致率 (入出力) を調べ た.a) の評価は HMM-SOM の学習によって自己組織化 された内部構造の認識率に相当するものであり，また b) の評価は, 結合重みの学習結果を示している.c) の評価は, 学習した認知行動システム全体の評価を意味している.評 価結果を図 8 に示す.グラフの横軸は学習回数を, 縦軸は 一致率を示す.このグラフを見ると, 知覚層, 結合, 入出力 ともに学習回数が増えるに従って一致率も増加する傾向 にあることがわかる.

また, 学習した内部構造を用いて, ロボットにボールの 軌道を知覚させ,対応した動きを生成するような認知行動 システムを構築した. このシステムは, ロボットにボール の軌道を見せると, 知覚層で最も尤度の高いノードを決定 し, 弚のノードと最も高い結合重みを持つ生成層のノード を決定する. 产の生成層のノードは, この参照 HMM のパ ラメータから関節角度時系列を出力する. ロボットはこれ を関節への指示值として両腕を動かす. このシステムで, 


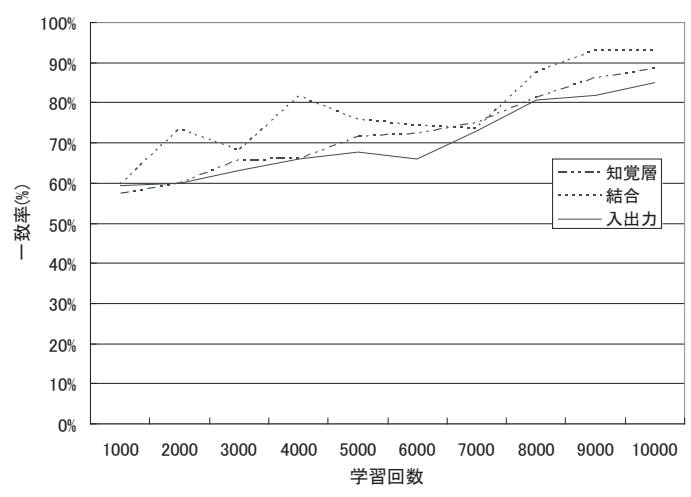

図 8 学習結果

ロボットにボールの動きを与えると, 教示した 3 つのパ ターンと対応する, ロボットの動きのパターンが発現する ことを確認した。

\section{$4 \cdot 2$ 音声による聞きまねシステム}

次に, 1 章で認知行動システムの一例として示した, ロ ボットが聞いた音を繰り返すという「聞きまね」システ ムの基礎的実験を行った.

\section{$\S 1$ 実験環境}

全体のシステム構成図を図 9 に示す. 本実験では, 認知 行動システムは $4 \cdot 1$ 節と同じものを使用しているが, 知 覚層への入力が音響分析器から出力される音声の特徵量, 生成層からの出力は音声合成ソフトウェアのパラメータ となる. 音響分析器は, マイクで収録した音声をサンプリ ング周波数 $22.05 \mathrm{kHz}$, フレーム長 $25 \mathrm{msec}$, フレーム周期 $10 \mathrm{msec}$ として音響分析を行う. 音響分析によって得られ る特徵量は, 音声認識で広く用いられているメルケプスト ラム (Mel Frequency Cepstrum Coefficients) の 13 次 元と, デルタメルケプストラム 13 次元, およびデルタデ ルタメルケプストラム 13 次元の計 39 次元である. また, 使用した音声合成ソフトウェアは, フレーム周期 $10 \mathrm{msec}$ のフォルマントの時系列とピッチ, パワーの時系列デー 夕合計 34 次元の時系列データから音声波形 (wav) を生 成する. この 34 次元の時系列データを生成層への入力, すなわちロボットの発声データとした. 学習は, 日本語の 単語 20 種類を男性 7 名が発声したデータ計 140 個を知 覚層への入力とし, 弚の音に対応するロボットの音声合 成パラメータを生成層への入力とした. 収録した単語の リストを表 1 に示す. 学習に用いた単語は, 音韻の長さ が同じで，母音の似た音韻を含むような単語が含まれる ようにに意識して (例:夕食と乗客/顔つきと買い置きな ど) 選択した. 学習データは, 収録した音声を単語ごとに 切り出したもの（前後に多少のポーズを含む）を使用した。 知覚層に与える学習データは, この音声を音響分析した 39 次元の時系列である. 一方, 生成層に与える学習デー

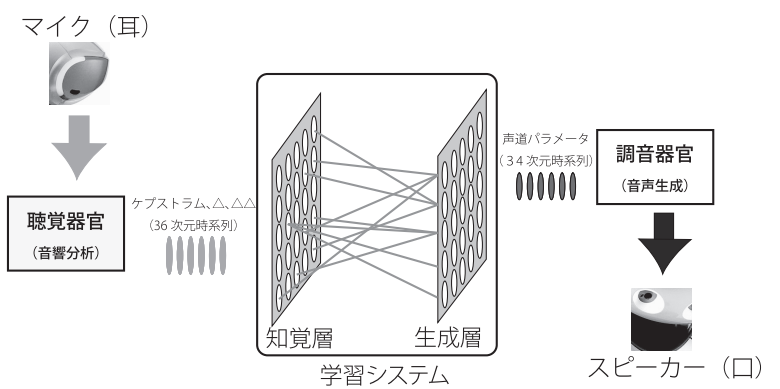

図 9 聞きまねシステム構成図

表 1 実験で使用した 20 単語

\begin{tabular}{|llll|}
\hline & & & \\
明け方 & 引力 & 海沿い & エプロン \\
鉛筆 & おしゃべり & おたふく & 買い置き \\
顔つき & 神樣 & 行政 & 公式 \\
乗客 & ステレオ & 手拭い & トロフィー \\
偽者 & 病人 & 持ち主 & 夕食 \\
& & & \\
\hline
\end{tabular}

タは,34 次元のパラメータ時系列となるが, これを手作業 で決定することはほぼ不可能である. 乥こで既存の音声 処理技術を使い, 音声データから対応する生成層の学習 データを, 半自動で作成した. まず, 音声認識器を用い, 収 録した音声データの音素列と光の継続長情報を得た. 次 に, 同じデータに対してピッチ解析を行い,ピッチ情報を 得た.この結果を目視で確認した上で，一般の音声合成技 術を使い, この 2 つのデータから,34 次元の音声合成パ ラメータ時系列の学習データを作成した.なお，使用した ソフトウェアは, 音声合成モジュールを除き, 自作のもの である.HMM-SOM のノード数は, 学習データ量が少な いことから, 1 カテゴリあたりのノード数を 5 ノード程度 割り当たるように, $100(10 \times 10$ のトーラス状) とし, これ にあわせて, $\alpha_{0}=0.4, \sigma_{0}=3.0$, 学習回数は 10000 回とし た.4・1 節の実験と同樣, 学習データは用意した学習データ 140 個から毎回ランダムにデータを選び, 繰り返し使用し た. また, 乥れ光れの SOM のノードの参照 HMM は,30 状態の left-to-right 型の HMM で構成した.HMM-SOM のノード数, 学習パラメータ,HMM の状態数は知覚層, 生 成層ともに同じパラメータを使用した。

\section{$\S 2$ 実験結果と考察}

まず, $4 \cdot 1 \cdot 2$ 節と同樣に a) 知覚層 b) 結合 c) 入出力の一 致率を調べた.評価データとして, 学習に使用しなかった 男性 4 名の話者が 20 単語を発声したデータ計 80 個を用 いた.この結果を図 10 に示す. 学習回数か増加するに従っ て一致率か増加していることから, 音声のような複雑な時 系列信号に対しても, 自己組織化学習が進んでいる樣子が 確かめられた. しかしグラフでは,8000 回をピークに光れ 光れの一致率か下がってきている. 学習バッファの状況も 


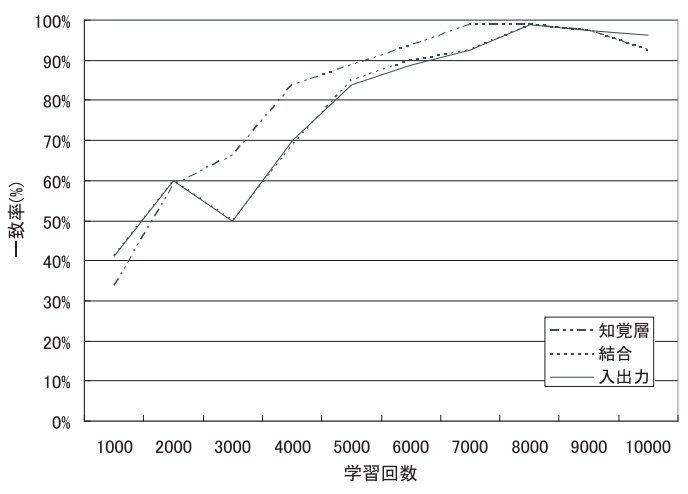

図 10 学習結果
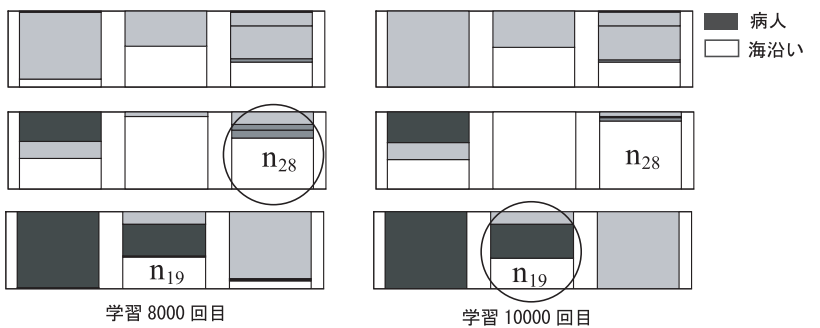

図 11 学習 8000 回目と 10000 回目の学習バッファの樣子 (一部)

含めてこの原因を分析したところ，ある種の過学習が起 こっていることが分かった.一例として，「海沿い」という 評価データで起きた現象を説明する.ノード $n_{19}, n_{28}$ 周辺 の学習バッファの変化の樣子を図 11 に示す. カテゴリラ ベル「海沿い」のある評価データに対して, 学習 8000 回 目の時には, ノード $n_{28}$ (擬似カテゴリラベル「海沿い」) が最も高い尤度を持っていた. しかし学習 10000 回目に なると, この評価データは, ノード $n_{28}$ の近傍 $n_{19}$ で知覚 されていた. このときノード $n_{19}$ の学習バッファは,「海 沿い」のカテゴリラベルを持つ学習データを約 $40 \%$ 含み, 「病人」の关れが約 43\%含まれるが, 擬似ラベルは僅差で 「病人」となり, 評価データのカテゴリラベルと擬似ラベ ルは不一致となる.一方, 学習 10000 回目でのノード $n_{28}$ の学習バッファを解析すると,「海沿い」のカテゴリラベ ルを持つデータが約 $89 \%$ 含まれていた. しかし, 学習パラ メータにより学習の最終段階では Winner-Takes-All の 学習となり, また学習データの種類が少ないため, 特定の 学習データに特化されすぎてしまったと推測される. 結 果として,ある「海沿い」の評価データに関しては, この ノードよりも,ノード $n_{19}$ の尤度の方が高くなってしまっ たと考えられる. 学習 10000 回目で不一致となった他の評 価データについても, この例と同樣の現象が見られた.こ の過学習の問題は, 学習の最終段階でWinner-Takes-All にする戦略と,ノード数に対しての学習データの少なさ によって起こる問題であると考えられる. 現状では, この 擬似的な認識率の評価においては過学習による性能低下
と見えるが, 最も尤度の高いノードの HMM には同じカ テゴリの学習データも多く含まれている. また, この過学 習の問題は学習データを増やすなどで解決できる問題で あると考察でき,HMM-SOM が持つ致命的な問題とは思 われない.

また, 評価データ群をこのシステムに入力したときに, 知覚層のどのノードが発火したかを調べた. この結果を 図 12 に示す. 図の各マスは知覚層の HMM-SOM のノー ドを示している. この知覚層に対して, 評価データを与え， 最も尤度の高かったノードを評価データの持つカテゴリ

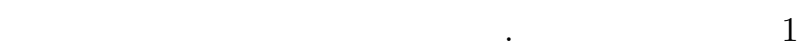
つあるいは近傍の複数のノードによって表現されている ことがわかる.HMM-SOM の特性を考えるなら,センサ 空間上で似た単語が付近に集まる傾向を持つと予想され る. 図 12 を見ると, 中央上部付近に「か」で始まる単語 「かおつき,かみさま,かいおき」が集まっていたり，「かお つき」と「こうしき」など主観的ではあるが音が似てい るものか隣り合う位置 (トーラスなので上部と下部は隣 接している) に配置されていたりする例はある.しかし， 客観的に見ると, 何か特定の傾向がはっきり見えるとは言 い切れなかった. この点は, 後の実験の議論でも触れる.

次に, 発火した知覚層のノードと, 結合重みがもつとも重 い生成層のノードを調べたものを図 13 に示す. 図上の光

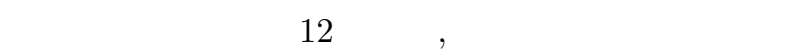
ベルと対応している. 図の各マスは生成層の HMM-SOM のノードを示している. この図から, 生成層にも単語ごと に,ある領域にある単語を表現するノードができているこ とが分かる.さらに, 図 10 を見ると, 学習 10000 回目では 結合重みが $90 \%$ 以上正しく獲得されていることから，光

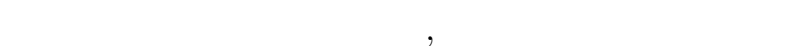
ゴリを表現するノードが発火していることが推測できる. 知覚層の分布 (図 12) と比較すると,HMM-SOM 上に表 現される単語の配置は異なっており,この異なった配置の 対応関係を結合重みによって学習できていることが分か る. 実際に HMM-SOM 上の参照 HMM から音声合成パ ラメータを生成し, 兴のパラメータから音声合成ソフト ウェアによって音声波形を生成して実際に音を確かめた. 产の結果, 多くの場合, 評価データのカテゴリラベルと一 致する音声を聞き取ることが出来た*3.

\section{$\S 3$ 日本語の音韻学習への適用}

上記の単語実験で, 100 ノードに 20 カテゴリの単語を 学習した例を示したが, 少し性質の異なるデータでの自 己組織化実験として,日本語の音韻 46 種類を学習させた. 実験システムは先の実験と同じものを用いた. 学習デー

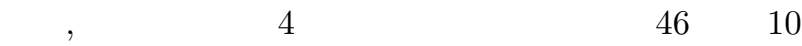
回発声したデータ計 3680 個と光れに対応するロボットの

\footnotetext{
*3 ここでは, 学習したカテゴリの単語を入力したときに关の単 語の音声を出力できたことについて言及している. 一方, $4 \cdot 3 \cdot 1$ 節では学習していない単語を入力したときの結果について言及 している
} 


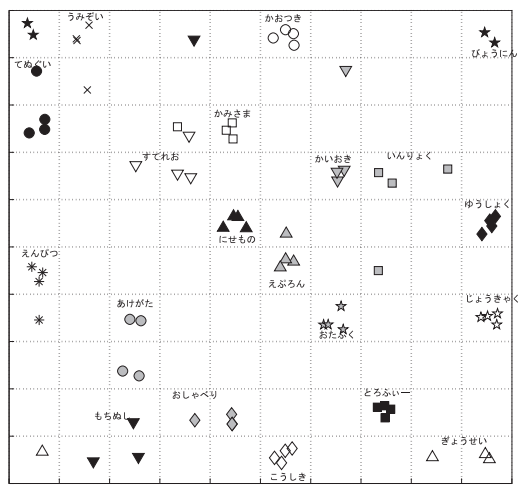

図 12 知覚層の HMM-SOM 上での評価データの発火

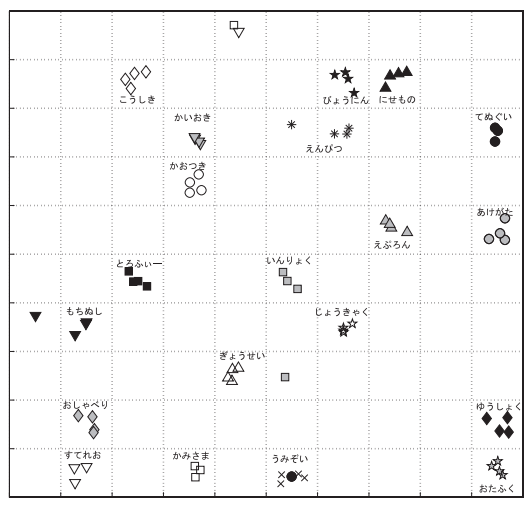

図 13 生成層の HMM-SOM 上での評価データの発火

発声データを用いた. 学習データの作成方法は $4 \cdot 2 \cdot 1$ 節 と同樣である. 使用した音韻 46 個を表 2 に示す.

本実験での HMM-SOM のノード数は, 1 カテゴリあた り $5 \sim 10$ 程度のノードか割り当たるよう, $20 \times 20$ の 400 個とし, これにあわせて $\alpha_{0}=0.8, \sigma_{0}=6.0$ とした. 本実 験でも学習中は用意した 3680 個の学習データの中から毎 回ランダムに選び, 繰り返し使用する. 学習回数は 50000 回とした. 弚れ攵れのSOM のノードに備えられる参照 HMM は,10 状態の left-to-right 型の HMM で構成した. 上記の条件で学習させたときの知覚層, 生成層の擬似力 テゴリラベルの分布, すなわち HMM-SOM に表現され た音韻の分布を図 14 に示す.このようにランダムにデー タを与え, 自己組織化学習を行った結果, 46 音は乥れに含 まれる母音によって大きく分類される構造を作った. その 大分類の中に, 各音が散らばつた構造を持つように知覚

表 2 実験で使用した 46 音韻

\begin{tabular}{|c|c|c|c|c|c|c|c|c|c|}
\hline あ & い & j & え & お & は & ひ & S & ح & ほ \\
\hline か & き & $<$ & け & $=$ & ま & み & む & め & $も$ \\
\hline さ & L & す & せ & 光 & や & & ゆ & & $よ$ \\
\hline た & $ち$ & $\supset$ & $\tau$ & と & ら & り & る & れ & 万 \\
\hline な & に & $ぬ$ & ね & の & わ & & を & & $h$ \\
\hline
\end{tabular}

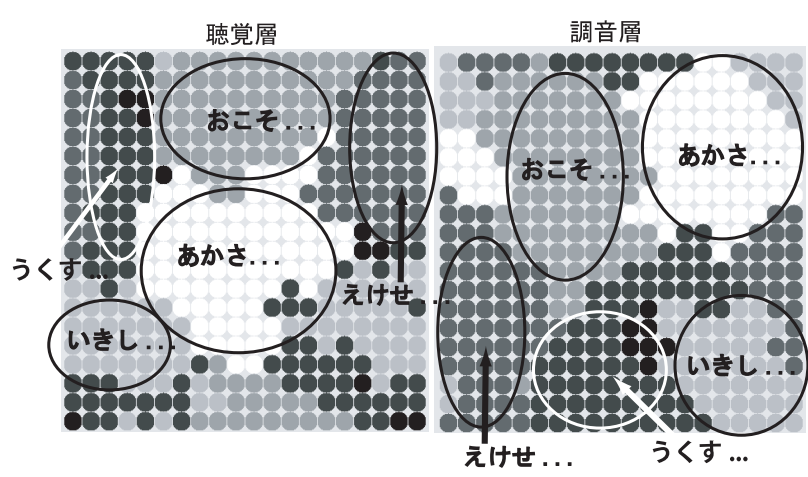

図 14 聴覚層, 調音層の音韻分布

層, 生成層が形成された.また, $4 \cdot 1$ 節の実験と同樣, 参照 HMM に設定した初期パラメータの值や学習データを与 える順序によって,HMM-SOM の学習結果は異なってい た. しかし,どの試行においても母音ごとの大きな領域が 構成され, 兴の中に各音韻か配置される構造が出来るこ とが観察された. これは,HMM の尤度という距離尺度に よって, 似た音韻が近傍に表現されるよう自己組織化学習 した結果, 似た音韻が近い領域に固まって表現されている ことを示している. 前節の単語の実験ではこういった傾向 か明には観測されなかったが,この例のように比較的単純 な信号の場合には, 顕著に弚の傾向を見ることができた.

また, 獲得された認知行動システムに対して, 学習デー タとして与えなかった音韻,例えば「う」と「え」の中間 音を入力した.すると，主観的ではあるが，「う」と「え」 の中間のような音が出力された. 入力した音韻は, 知覚層 の「う列」の領域と「え列」の領域の間のノードで知覚 された. 乥して㚇のノードと最も高い結合重みを持つ生 成層のノードも同樣に「う列」の領域と「え列」の領域 の間に位置していた.このような現象は, 獲得した内部構 造が経験したことがない入力に対して, 経験したものと は違う,且つ人間が合理的に見えるような内挿を出力し ている例であると言える.

\section{$4 \cdot 3$ 考 察}

$\S 1$ 未知の入力に対する認識生成能力について

これまでに述べた各実験では, 提案手法がカテゴリ構 造を持つ学習データを自己組織的に学習でき, 認識生成 を行えることを, 実世界のデータを用いて示してきた.し かし 1 章で述べたように, 認知行動システムは, 未知の入 力に対する妥当な出力も可能であることが望ましい. こ こでは光の一例として, 学習したカテゴリ間の内挿に着 目して考察を深める.

まず提案する認知行動システムが持つ, 学習したカテ ゴリ間の内挿の表現能力について, 簡単な追加実験を行つ た. 具体的には, シミュレーション環境で振幅の違う(こ こでは 0.3 と $\left.0.5^{* 4}\right) 1$ 周期, 126 フレームの正弦波を学習

$* 4$ 学習データには各フレームの値に対し, 分散が光の $5 \%$ とな 
表 3 実験条件

\begin{tabular}{|c|c|}
\hline HMM の状態数 & 20 状態 \\
\hline 学習回数 & 1 万回 \\
\hline HMM-SOM の大きさ & $9(3 \times 3)$ \\
\hline
\end{tabular}

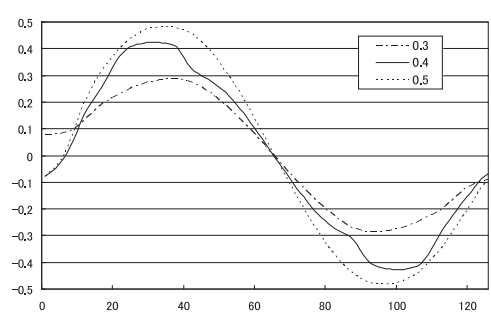

図 15 正弦波による追加実験の出力

データとして与えて学習した認知行動システムに対して 振幅 0.3,0.4,0.5 の正弦波を入力したときの樣子を観察し た.このとき, 振幅 0.4 の正弦波は, 認知行動システムに とって未知の信号となる. 学習には知覚層と生成層の信 号データ対が必要であるが, 振幅 0.3 の波形に対して振 幅 0.3 の波形, 振幅 0.5 の波形には振幅 0.5 の波形振幅を 対応させて用意し,認知行動システムに学習させた.この 追加実験の実験条件を表 3 に, 学習後のシステムに振幅 が 0.3,0.4,0.5 の正弦波を入力した際の出力を图 15 に示 す. 実験設定から, 知覚層に入力したものと同じ振幅の正 弦波が出力されることが期待される.HMM のモデル化能 力による波形の歪みが若干あるものの, 振幅 $0.3,0.5$ では ほぼ光れに近い波形が出力されている. また振幅 0.4 の 入力に対しては, 波形の歪みは大きくなるものの, 学習し た振幅の中間的な振幅となる正弦波が出力されることを 確認した. この出力を定量的に評価するため, 光れ振 幅 0.3,0.4,0.5 の正弦波を認知行動システムに入力したと きの出力に対して, 弚れ光れの場合の正解に相当する振 幅が $0.3,0.4,0.5$ の正弦波との 1 フレームあたりの平均 2 乗誤差を表 4 に示す. 振幅が $0.3,0.5$ という学習した波形 だけでなく,振幅が 0.4 の入力に対しても, 正解である振 幅 0.4 の正弦波との誤差が小さくなっていることがわか る. 非常に基本的な検証ではあるが, 本手法による内挿表 現の実例を, 定量的評価とともに確認した.

次に, $4 \cdot 1$ 節, $4 \cdot 2$ 節の実験で学習した認知行動システム に対して, 学習に使用したカテゴリ以外のデータを入力し たときの出力を観察した. $4 \cdot 2 \cdot 3$ 節では, 主観的ではあるが 学習していない音韻 $(4 \cdot 2 \cdot 3$ 節では「う」と「え」の中間 音について説明した) が知覚生成されることを確認した。 これは, 提案した認知行動システムで, 学習結果としての カテゴリの内挿が HMM-SOM 上の参照 HMM に表現さ れ，弚れがうまく使われたことを示している.一方, $4 \cdot 2 \cdot 1$ 節の実験では, 4 文字の適当な単語を入力すると, 知覚層 では学習したカテゴリとは異なるノードが発火し, 乥れ
表 4 正解に対する誤差

\begin{tabular}{|c|c||c|c|c|}
\hline \multicolumn{2}{|c||}{} & \multicolumn{3}{c|}{ 正解の正弦波の振幅 } \\
\cline { 3 - 5 } \multicolumn{2}{|c|}{} & 0.3 & 0.4 & 0.5 \\
\hline \hline \multirow{3}{*}{ 入力した正弦波の振幅㣂 } & 0.3 & 0.0204 & 0.0726 & 0.1255 \\
\cline { 2 - 5 } & 0.4 & 0.0738 & 0.0376 & 0.0679 \\
\cline { 2 - 5 } & 0.5 & 0.1354 & 0.0724 & 0.0374 \\
\hline
\end{tabular}

に対応した生成層のノードも学習したカテゴリを代表す るノードとは異なるノードが発火した. しかし, 生成層の 発火したノードから音声を出力して聞いてみると, 単語 の音韻が聞き取れない音が発声された. また, $4 \cdot 1$ 節の視 覚と運動の対応実験は, 教示したことがない斜めに動く ボールの軌道を提示すると, ロボットは縦の動きなどのす でに学習したことがある動作を出力する現象が多く見ら れた.このとき知覚層,生成層の HMM-SOM を分析する と,複数のカテゴリの学習データによって学習された参照 $\mathrm{HMM}$ も存在しており, この HMM から出力を生成して みると, 教示したカテゴリとは異なる中間的な動作は生 成できた.しかし, 実際にボールを斜めに動かしてみると, 知覚層の複数の学習データからなる中間的なノードが発 火せずに, 教示したカテゴリを代表するノードが発火し てしまい, 中間的な動作が出力できないことがわかった.

これらの事例から, 本手法の内挿能力及び内挿に関連す る問題点をまとめてみる. 提案した認知行動システムで, 本節で示した追加実験や音韻学習のような比較的単純な 波形では, 学習したカテゴリ間の内挿が表現される例を明 確に確認できた. 一方で $4 \cdot 2 \cdot 1$ 節で見られるように, 単語 のような複雑な時系列信号を扱った場合,HMM-SOM の 空間で音声として有意味な未知の単語が内捙として表現 されることは起こりにくいことがわかった.この一つの理 由は, 多次元時系列をある低次元空間にマップしたとき, 弚の低次元空間での中間的な構造が, 元の空間で有意味な 入出力を表現することの困難性にあると思われる.また, $\ulcorner$ 内挿の多樣性」も重要な要因である. 例えば, $4 \cdot 2 \cdot 3$ 節の 音韻の実験では, 「う」と「え」の中間的な音声が出力さ れた事例があった一方で, 「あ」と「い」の内挿表現とし て「あい」といったという音声が出力される例も観察さ れた.この HMM は,「あ」と「い」の学習データからパ ラメータ更新されていたが,HMM の各状態の前半部ので は「あ」をモデル化し, 後半部では「い」をモデル化して いるものと推測できる. この「あい」という音声は我々人 間の考える内挿とは直感的に異なるが，ある意味で両者 の内插である.このような内挿の多樣性によって, 我々の 直感に見合う内挿が HMM-SOM 上に表現されていない ことも考えられる. 有意味な内挿は問題設定によって異な り, 現時点では光の内挿を得るための一般則は見出せて いない.

また $4 \cdot 1$ 節の結果は, 中間的出力がうまく出せない理由 


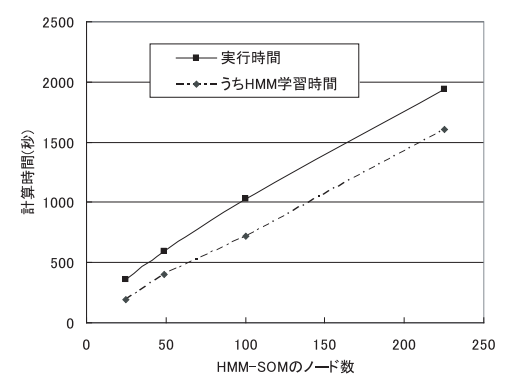

図 16 ノード数の違いによる HMM-SOM の計算量

表 5 実行時間計測の実験条件

\begin{tabular}{|c|c|}
\hline HMM の状態数 & 10 \\
\hline 学習回数 & 1 万回 \\
\hline 入カデータ & 1 次元 126 フレーム \\
\hline HMM-SOM のノード数 & $25,49,100,225$ \\
\hline
\end{tabular}

として, 複数の学習データから学習された HMM が, 我々 が内挿と考えている入力に対して, 勝者ノードとなれな いケースの存在を示している. これは先に述べた内挿の 多樣性と深く関係しており, システムが作った内挿を人 間が想像できていない場合も考えられる.また,HMM が 時間伸縮を許容する尤度計算を行っていることから, 我々 の直感と食い違う勝者ノードが選択されることも原因と 考えられる. このような人間の主観との不一致をどのよ うに埋めるかは, 今後の重要な課題である.

$\S 2$ 計算量について

提案する認知行動システムの計算量は,HMM-SOM の ノードの数に比例して増加する.HMM-SOM の学習にお いて,HMM-SOM のノードの数と実行時間の関係を図 16 に, 弚の際の実験条件を表 5 に示す.このシステムでは HMM-SOM の学習, 中でも HMM のパラメータ推定に かかる計算時間か汥配的である.HMM のパラメータ推定 にかかる計算量は,HMM の状態数, 入力データの次元数, 入力データのフレーム長に比例する. 兴のため, 音声のよ うな多次元の時系列信号を扱う場合には, 計算コス卜を 要することになる. 本稿での実験では, 学習データをオフ ラインで与えているが, オンラインでの学習を視野にい れれば, 計算量の削減は今後の課題となる.

\section{5. 議 論}

\section{$5 \cdot 1$ 関 連 研 究}

HMM を用いた時系列信号のモデル化，モデルを用い た認識/生成という点では, 稲邑らの研究が挙げられる [Inamura 02]. 稲邑らは人間が行っている「見まね」に着 目し, 相手の行動の観測を通じてシンボルとして認識し， ぞのシンボルから自分の行動を再現するプロセスを工学 的にモデル化することを試みている. 具体的には, 入力信 号と出力信号はともに関節角度時系列を扱い, ロボット
や人間の運動パターンを HMM によって抽象化し，この HMM を原始シンボルとして捉え，この HMM によって 認識,生成を行うモデルを提案している. 我々の提案した 認知行動システムでは, 入力信号と出力信号が必ずしも同 じモダリティである必要はなく, 入力信号と出力信号の抽 象化に加えて, 乥の写像を学習するというモデルになって いる. また稲邑らは, この原始シンボルを複数作成し, 光 れらの間の距離を定義して多次元尺度法によって空間上 に配置することで, 原始シンボル同士の関係性を持たせて いる [Tanie 03]. これによって, 原始シンボル空間上で例 えば内分点を取るといった, 幾何学的な空間での操作に基 づいて, 原始シンボルの組み合わせとなる新規運動の認 識, 生成が可能であることを示している.一方我々のアプ ローチでは,HMM を $\mathrm{SOM}$ 上に配置することで, 入力信 号を参照 HMM にモデル化していく学習と同時に,SOM 上のトポロジー空間によって自己組織的に HMM 同士の 関係も学習している.すなわち, 学習データとして与えら れたカテゴリ間の内挿が HMM-SOM の学習過程を通し て参照 HMM に表現されていく.

SOM とモジュールを組み合わせるというアーキテク チャの観点からは, 中村らの提案しているダイナミカル SOM[Nakamura 03] と,2 2 節で触れた德永らの提案す る mnSOM[Tokunaga 05] が挙げられる. 前者は,SOM の参照ベクトルを力学系に置き換えることで, 時系列信号 の自己組織化を実現している.ダイナミカル SOM は時系 列信号を自己組織的に学習し構造化を行うという点で, 本 研究と目的は共通している. 一方で, ダイナミカル $\mathrm{SOM}$ では入力信号から次の時刻の入力信号を予測する予測モ デルになっているため, 入出力が同じ信号を扱うことにな る. 本研究ではモダリティの違うセンサ-モータ間の関係 を自己組織的に学習することを目的としており, 光のため に知覚層-結合層-生成層という構成のアーキテクチャを提 案している. また, 音声のような複雑な時系列信号を扱う ために音声認識で実績のある HMM に着目し,SOM のモ ジュールとして配置したことが本研究の特徵である. 後者 は多層パーセプトロンを SOM 上に配置し, 各ノードに入 出力関係を持たせた $\mathrm{mnSOM}$ (モジュラーネット型 $\mathrm{SOM}$ ) を提案している.mnSOM と我々が提案した HMM-SOM とは,SOMのノードにモジュールを配置する点, 未学習の データや入出力関係を SOM の中間ノードを用いて表現 しょうとする点で共通している.一方相違点を考えると， 我々は知覚層, 生成層, 写像というアーキテクチャで認知 行動システムを構成しているのに対して, 德永らは $1 つ$ のSOM 空間で入出力関係を持たせている. 先にも述べた ように本研究ではこのアーキテクチャを用いることで入 出力のモダリティの違う多次元の時系列信号同士のセン サ-モータの関係を学習することを可能としている.さら に, 本稿で述べた実験では 1 つの知覚層に対して対応す る 1 つの生成層への写像を学習しているが, 自律エージェ ントが持つべき認知行動システムは, 本来複数のモダリ 
ティから構成されるものであり,複数のモダリティ間の入 出力を学習する必要性がある. 我々の提案するアーキテク チャは, 1 つの知覚層から複数の生成層への写像を作るよ うな, 1 対多, 多対 1 のモダリティ間の写像関係を作るこ とが可能であり, 複数モダリティへの拡張が容易であると 考えている. また, 我々は入出力信号を低次元化すること は, 多次元の複雑な時系列信号間の入出力関係を学習する のに有効な手段であると考えている. 乥こで本稿では, 入 出力信号を HMM-SOM を用いて低次元化した上で, 光 の入出力関係を Hebb 学習の拡張という簡単なモデルで 学習することを提案し，この手法が有効であることを実 験を通して示した. 入出力信号の低次元化と入出力関係 の学習という組み合わせで考えれば, 入出力信号を我々の 提案する HMM-SOM で低次元化した上で,mnSOM に よる入出力関係の学習を行うという両者の技術を組み合 わせたアーキテクチャも考えることができるだろう.

入出力が異なる信号を扱った認知行動システムの学習 という点では, 吉川らは母子間の相互作用モデルによるロ ボットの音声模倣学習を提案している [Yoshikawa 03]. こ の音声模倣学習は, 1 章て触れた養育者の「まね」に着目 し, ロボットのランダムな発声に対して, 養育者が社会に 存在する音と判断した場合に, 弚の音を繰り返して正解を 与えるという学習方法により,ロボットが社会の音韻を獲 得していくものである. これは, ロボットの発声のモータ コマンドと, 光れに対応するセンサ信号を対として, 両者 の入出力関係を学習していることになり,我々の提案する システムと学習手法は共通している. また, この研究での ロボットシステムは, 我々のアプローチと同樣, 認知シス テムを聴覚層と構音層, 光の層の間の結合という形でモデ ル化している.しかし, 吉川らは入力信号として, フォルマ ントベクトルを扱い, 出力信号として構音ベクトルを扱っ ているため, 聴覚層も構音層も静的なべクトルを扱ってい る.これに対して我々のアプローチは,HMM-SOM を用 いることで, 聴覚-調音の対応付け問題として時間変化の ある単語や子音などを扱うことを可能としている.

\section{$5 \cdot 2$ 課 題と展 開}

一連の実験を通して,提案した手法による自己組織的な カテゴリ形成, またそ㢳間の写像構築の能力を検証した 複雑な時系列信号を扱った実験ではあったが, カテゴリの 数は最大でも数十程度の問題しか検証していない. まず もっと大規模な実験を行い, 構造生成の可能性, 安定性を 検討する必要がある. 学習データに含まれない入力に対す る中間的な構造の生成については, 提案した認知行動シス テムで, 学習結果としてのカテゴリの内挿が HMM-SOM 上の参照 HMM に表現され, この HMM が末知の入力に 対しての出力を可能にしていた現象を $4 \cdot 2 \cdot 3$ 節や $4 \cdot 3 \cdot 1$ 節で示した. しかし, 例えば単語のような複雑な時系列信 号を扱った場合, 弚の空間で音声として有意味な未知の単 語が内挿として表現されることは非常に起こりにくいこ
とや, 内挿を表現するノードができるものの, 内挿の多樣 性によって認識, 生成時に利用できない場合があることも わかった.いかにして, 有意味な内挿表現を構成し，かつ 認識生成に利用できるものにするかという問題は, 取り 組むべき重要な課題である. 一方で, 最初から内挿が十分 な意味を持てなくても, 後で述べる自律的な探索をして いく際の初期値として使える可能性は十分にある. こう いった別の観点との融合も積極的に考えていきたい.

本研究全体の動機付けとして,認知行動にシステムに おける教示やものまねの重要性を挙げ, 人間の音声獲得の 事例を述へた.この認知行動システムを実現するべく, 本 稿では, センサ信号と光れに対応するモータ信号を直接教 示で与え, 学習により自己組織的に内部構造か構築できる ことを示した.しかし,例えば乳児が音韻を習得していく 過程では, 与えられるのはセンサ信号の教示のみであり, 声帯の動きは自己探索により習得していくものであるよ うに, 現実世界で直接教示によってモ一タ信号を教示で きる例は少ない. 1 章で触れたように, エージェント自身 が,「まねる」行為を行うためには, 目標センサ状態を定 め, モ一夕信号を探索し, 新たなモー夕信号系列を産み出 すメカニズムが認知行動システムに必要であると考えて いる.このような認知行動システムにおける自己探索に よる新たな行動の獲得は今後の課題である.

\section{6. ま と め}

本論文では, 入力信号と出力信号の対応関係を獲得する, 認知行動アーキテクチャを提案した.この認知行動アーキ テクチャは,HMM-SOM による時系列信号の自己組織化 と光の間の写像関係を同時に学習する. このアーキテク チャの基本能力を検証するために, まず「視覚-運動」の 検証を行った. 乥して認知行動システムの発達の一例とし て示した「聞きまね」システムを構築し,多次元時系列信 号の入出力関係が連続的な構造を持って獲得できる可能 性を示した.より具体的には, 自己組織的な構造獲得, 中 間的な入力に対して中間的な出力を可能とする構造の獲 得が可能であることを, 限られた事例ではあるか確認でき た.SOM の自己組織的な学習は, 学習データ間の関係を 同時に学習することができ, 光して光の学習データを表 現する代表的なノード同士の間に, 中間的な表現を形成 する. この特徵と HMM との組み合わせにより,多次元の 時系列データでの自己組織化学習を可能にし, 知覚層-結 合層-生成層のモジュール構成をとることで, 異なるモー ダル間の間の対応関係においても内挿を表現できる可能 性があることを実験を通して示した.一方でより適切な 認知行動のためには, 複雑な多次元時系列信号に対する 汎化された構造の獲得,さらに自己の探索による新たな 行動の創発メカニズムが必要であり, 今後の課題となる. 


\section{謝辞}

本研究を進めるにあたりこ協力いただいた, ソニー (株) の 2 足歩行ロボットのハードウェア, ソフトウェア研究開 発の関係者各位に深く感謝申し上げます。

\section{$\diamond$ 参 考 文 献 $\diamond$}

[Asada 01] Minoru Asada, Karl F.MacDorman, Hiroshi Ishigro, and Yasuo Kuniyoshi," Cognitive developmental robotics as a new paradigm for the design of humanoid robots," Robotics and Autonomous System,Vol.37, pp.185193, 2001.

[Fujita 03] M.Fujita,et al,"Autonomous Behavior Control Architecture of Entertainment Humanoid Robot SDR-4X," Proc. of IEEE/RSJ International Conference on Intelligent Robots and Systems 2003, pp.960-967,2003.

[Hebb 49] D.O.Hebb,"The Organization of behavior,"Wiley, 1949

[Inamura 02] 稲邑他,”ミメシスに基づくヒューマノイドの行動 獲得と原始シンボルの創発”, 日本人工知能学会全国大会 (第 16 回) 予稿集,pp.1D1-02,2002.

[Kohonen 95] T.Kohonen,"Self-Organizing Maps," SpringerVerlag, 1995

[Masataka 93] 正高 信男,"0 歳児がことばを獲得するとき-行動 学からのアプローチ-", 中公新書,1993.

[Minamino 05] K.Minamino, et al,"Voice imitation based on self-organizing maps with HMMs," Proc. of Humanoids2005 Workshop on Intelligence Dynamics, pp.25-30, 2005.

[Nakamura 03] 中村他,”自己組織化的にシンボルの獲得を行う ロボットの力学的情報処理”, 第 21 回 日本ロボット学会学術講 演会, 2003,3K34.

[Tanie 03] 谷江他,"ミメシスの数学モデル:隠れマルコフモデル を用いた階層的原始シンボル空間における運動の認識と生成”, 日本機械学会ロボティクス・メカトロニクス講演会 2003 講演 論文集,pp.2P2-3F-B3,2003.

[Tokunaga 05] 徳永他,"関数空間型 SOM, "日本神経回路学会 誌,Vol.12,No.1,pp.39-51,2005.

[Yoshikawa 03] Y. Yoshikawa, et al," Primary Vowel Imitation between Agents with Different Articulation Parameters by Parrot-like Teaching," Proc. of IEEE/RSJ International Conference on Intelligent Robots and Systems 2003, pp.149154, 2003.

\section{〔担当委員：小松 孝德〕}

2006 年 7 月 20 日 受理

$$
\diamond \text { 付 録 } \diamond
$$

\section{A. 重み付き学習データを用いた HMM パラメータの更新}

Baum-Welch の学習アルゴリズムによる HMM のパラメータ推 定法は以下の式によって与えられる. 初期パラメータ $\phi$ で与えられ る HMM の状態 $i$ から状態 $j$ への状態遷移確率を

$$
f_{i j} \quad(i=0, \ldots, M, j=0, \ldots, M)
$$

状態 $j$ の出力確率密度関数を

$$
g_{j}(x)=N\left(x, \eta_{j}, \rho_{j}^{2}\right) \quad(j=1, \ldots, M-1)
$$

とする. ここで, $N\left(x, \eta_{j}, \rho_{j}^{2}\right)$ は平均 $\eta_{j}$, 分散 $\rho_{j}$ の正規分布で与え られる確率密度関数である.

この初期パラメータ $\phi$ に基づいて, 時刻 $t$ に状態 $i$ にいる前向き 確率を $\alpha_{i}(t)$, および時刻 $t$ に状態 $i$ にいる後ろ向き確率を $\beta_{i}(t)$ と して, 観測時系列データ $x=x_{1}, \ldots, x_{T}$ が与えられた時の状態遷移
確率 $a_{i j}$ は, 以下の式で計算される.

$$
a_{i j}=\frac{\sum_{n=1}^{N} \frac{1}{P_{\phi}\left(x^{n}\right)} \sum_{t=1}^{T_{n}-1} \alpha_{i}^{n}(t) f_{i j} g_{j}\left(x_{t+1}^{n}\right) \beta_{j}^{n}(t+1)}{\sum_{n=1}^{N} \frac{1}{P_{\phi}\left(x^{n}\right)} \sum_{t=1}^{T_{n}} \alpha_{i}^{n}(t) \beta_{i}^{n}(t)}
$$

但し,

$$
P_{\phi}(x)=\alpha_{M}(T)=\beta_{0}(1)
$$

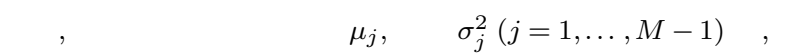
下の式によって求められる.

$$
\begin{aligned}
\mu_{j} & =\frac{\sum_{n=1}^{N} \frac{1}{P_{\phi}\left(x^{n}\right)} \sum_{t=1}^{T_{n}} \alpha_{j}^{n}(t) \beta_{j}^{n}(t) x_{t}^{n}}{\left.\sum_{n=1}^{N} \frac{1}{P_{\phi}\left(x^{n}\right)}\right) \sum_{t=1}^{T_{n}} \alpha_{j}^{n}(t) \beta_{j}^{n}(t)} \\
\sigma_{j}^{2} & =\frac{\sum_{n=1}^{N} \frac{1}{P_{\phi}\left(x^{n}\right)} \sum_{t=1}^{T_{n}} \alpha_{j}^{n}(t) \beta_{j}^{n}(t)\left(x_{t}^{n}\right)^{2}}{\sum_{n=1}^{N} \frac{1}{P_{\phi}\left(x^{n}\right)} \sum_{t=1}^{T_{n}} \alpha_{j}^{n}(t) \beta_{j}^{n}(t)}-\mu_{j}^{2}
\end{aligned}
$$

HMM-SOM では, 観測された時系列データ $x^{k}=x_{1}, \ldots, x_{T}$ が 学習データとなり, 勝者ノードからの SOM 空間での距離に応じて, 重み $w^{k}$ が付与され, この重みを考慮して HMM のパラメータ推 定を行う. 学習バッファに保持されている学習データを $x^{1} \ldots x^{N}$ と し, 対応する重み項を $w^{1} \ldots w^{N}$ とすると, 状態遷移確率 $a_{i j}$ は, 式 (A.3) に重み項 $w^{k}$ が加わり, 以下の式で計算される.

$$
a_{i j}=\frac{\sum_{n=1}^{N} \frac{1}{P_{\phi}\left(x^{n}\right)} \mathbf{w}^{\mathbf{n}} \sum_{t=1}^{T_{n}-1} \alpha_{i}^{n}(t) f_{i j} g_{j}\left(x_{t+1}^{n}\right) \beta_{j}^{n}(t+1)}{\sum_{n=1}^{N} \frac{1}{P_{\phi}\left(x^{n}\right)} \mathbf{w}^{\mathbf{n}} \sum_{t=1}^{T_{n}} \alpha_{i}^{n}(t) \beta_{i}^{n}(t)}
$$

同樣にして光れ光れの状態の平均 $\mu_{j}$, 分散 $\sigma_{j}^{2}(j=1, \ldots, M-1)$ は式 (A.5)(A.6) に重み項 $w^{n}$ がかかり, 以下の式で計算される.

$$
\begin{aligned}
\mu_{j} & =\frac{\sum_{n=1}^{N} \frac{1}{P_{\phi}\left(x^{n}\right)} \mathbf{w}^{\mathbf{n}}{ }_{t=1}^{T_{n}} \alpha_{j}^{n}(t) \beta_{j}^{n}(t) x_{t}^{n}}{\sum_{n=1}^{N} \frac{1}{P_{\phi}\left(x^{n}\right)} \mathbf{w}^{\mathbf{n}} \sum_{t=1}^{T_{n}} \alpha_{j}^{n}(t) \beta_{j}^{n}(t)} \\
\sigma_{j}^{2} & =\frac{\sum_{n=1}^{N} \frac{1}{P_{\phi}\left(x^{n}\right)} \mathbf{w}^{\mathbf{n}} \sum_{t=1}^{T_{n}} \alpha_{j}^{n}(t) \beta_{j}^{n}(t)\left(x_{t}^{n}\right)^{2}}{\sum_{n=1}^{N} \frac{1}{P_{\phi}\left(x^{n}\right)} \mathbf{w}^{\mathbf{n}} \sum_{t=1}^{T_{n}} \alpha_{j}^{n}(t) \beta_{j}^{n}(t)}-\mu_{j}^{2}
\end{aligned}
$$

また, 初期パラメータ $\phi$ は,HMM-SOM の参照 HMM のパラメー 夕の更新時には, $k$ 番目に入力された観測時系列データ $x^{k}$ を学習す る場合, $x^{k}-1$ か観測された時に HMM のパラメータ推定を行った ときの, 参照 HMM の持つ HMM のパラメータを使用している. 


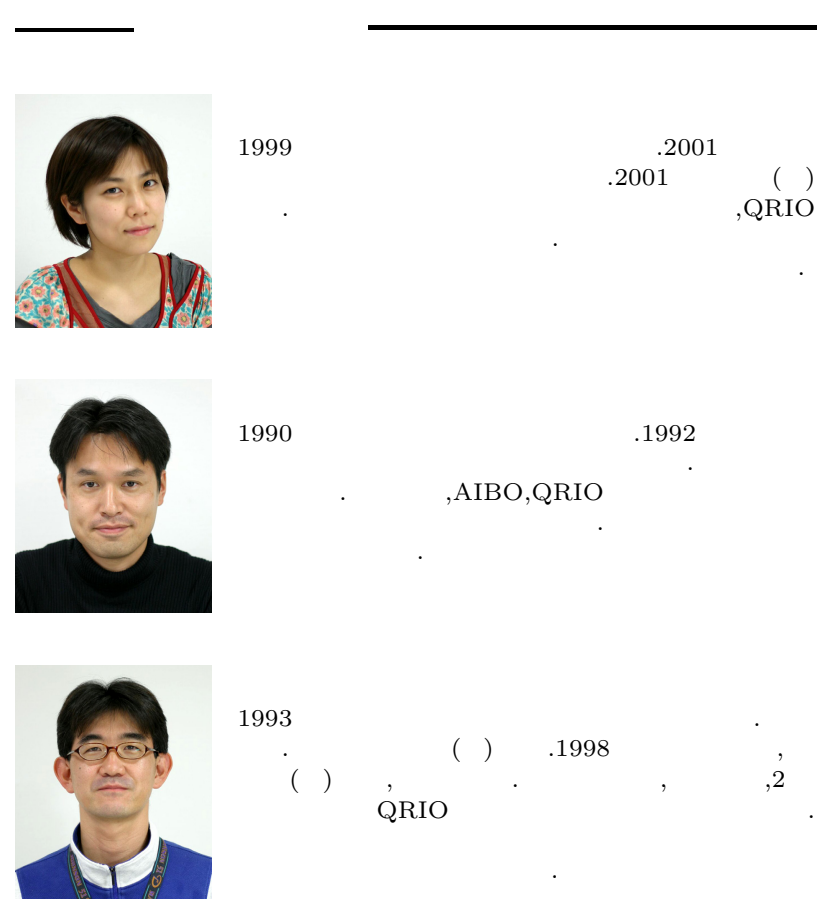

